\title{
Investigation of Colistin Heteroresistance and Some Factors Affecting Heteroresistance in Carbapenem-Resistant A. baumannii Strains
}

\author{
Karbapenem Dirençli A. baumannii Suşlarında, Kolistin Heterojen Direncinin ve Buna Etki \\ Eden Bazı Faktörlerin Araștırılması
}

\author{
Deniz GAZEL1, Müşerref TATMAN OTKUN2 \\ 1 Gaziantep University Faculty of Medicine, Department of Medical Microbiology, Gaziantep, Turkey \\ ${ }^{2}$ Çanakkale Onsekiz Mart University Faculty of Medicine, Department of Medical Microbiology, Çanakkale, Turkey
}

\section{Abstract}

Introduction: Colistin can be used in patients infected with carbapenem-resistant Acinetobacter baumannii complex (CR-ABC), but recently resistance to colistin and heteroresistance have been reported. In this study we aimed to investigate the colistin heteroresistance rates and the effects of colistin and its combinations on colistin heteroresistance/resistance development in CR-ABC strains in our hospital.

Materials and Methods: Heteroresistance analysis was performed on CR-ABC isolates and standard ABC strain [American Type Culture Collection (ATCC) 19606)] strain. To investigate hidden heteroresistance, the isolates were exposed to colistin at sub-inhibitory concentrations. 'Time-kill' study was performed on the standard strain and a clinical strain for colistin. Serial passage test was performed to investigate the effects of drug combinations on heteroresistance/resistance development.

Results: In the first heteroresistance analysis test, all strains were found to be non-heteroresistant. However, after sub-inhibitory exposure to colistin, colistin heteroresistance/resistance developed in all isolates. In serial passages, colistin-rifampicin and colistin-tigecycline (Col+Tig) combinations were found to be effective and prevented growth of colistin-resistant sub-populations even at sub-inhibitory doses. Colistin-gentamicin (Col+Gen) combination was not found to be effective against the clinical isolate while it was effective on ATCC strain. Colistin-fluconazole combination was found to be ineffective at all concentrations.

Conclusion: In our study, it was shown that the strains which were detected to be non-heteroresistant could easily transform to heteroresistant/ resistant forms after exposure to colistin. Colistin-rifampicin and Col+Tig combinations were found to be effective and prevented the emergence of heteroresistance/resistance to colistin even at low concentrations. At low concentrations, Col+Gen combination was ineffective against the clinical $A B C$ isolate. Colistin-fluconazole combination failed to inhibit the emergence of resistant bacteria. Heteroresistance or resistance to colistin may easily develop because of inappropriate use of this antibiotic. To prevent this condition, colistin should be administrated at appropriate doses and in combination with the suggested antibiotics.

Keywords: Colistin, carbapenem, combination, heteroresistance, rifampin

\section{Öz}

Giriş: Kolistin, karbapenem dirençli Acinetobacter baumannii kompleks (CR-ABC) enfeksiyonu olan hastalarda kullanılabilecek seçeneklerdendir ancak son zamanlarda kolistin için de direnç ve heterodirenç bildirilmiştir. Bu çalışmada hastanemizde izole edilen CR-ABC suşlarında, kolistin heterojen direnç oranını ve kolistinin ve bu ilacın ikili kombinasyonlarının kolistin heterodirenç/direnç gelişimi üzerine etkilerini araştırmayı amaçladık.

Gereç ve Yöntem: Karbapenem dirençli A. baumannii izolatları vve standart ABC suşu [American Type Culture Collection (ATCC) 19606] üzerinde heterojen direnç analizi yapıldı. Gizli heterodirenç/direnci ortaya çıkarabilmek için, izolatlar sub-inhibitör konsantrasyonlarda kolistine maruz bırakıldı. Standart suş ve bir klinik izolat üzerinde kolistin için 'time-kill' çalışması yapıldı. İlaç kombinasyonlarının heterodirenç/direnç gelişimi üzerine etkilerini incelemek için seri pasaj deneyleri yapıldı. 
Bulgular: Yapılan ilk heterodirenç analizinde hiçbir suşta heterodirenç saptanmadı. Ancak sonrasında sub-inhibitör dozda kolistine maruz bırakılan tüm izolatlarda kolistine heterodirenç/direnç gelişti. Seri pasajlarda, kolistin-rifampisin, kolistin-tigesiklin kombinasyonları sub-inhibitör dozda bile kolistin dirençli alt popülasyonların üremesini engelledi. Kolistin-gentamisin kombinasyonu ATCC suşu için etkili iken, klinik izolatta etkili olamadı. Kolistin-flukonazol kombinasyonu ise tüm dozlarda etkisiz bulundu.

Sonuç: Çalışmamızda heterojen dirençli gözükmeyen suşların, kolistin maruziyeti sonrasında kolayca heterodirençli/dirençli hale gelebilecekleri gösterildi. Kolistin-rifampisin, kolistin-tigesiklin kombinasyonlarının düşük dozlarda bile heterodirenç/direnç gelişimini engellediği saptandı. Kolistin-gentamisin kombinasyonu ise düşük dozlarda klinik izolatta etkisiz bulundu. Kolistin-flukonazol kombinasyonu dirençli bakteri oluşumunu önlemede etkisiz bulundu. Uygunsuz kolistin kullanımı ile bu antibiyotiğe karşı direnç/heterodirenç kolaylıkla gelişebilir. Bunu engellemek için kolistin, mutlaka uygun dozlarda ve önerilen antibiyotiklerle kombine olarak kullanılmalıdır.

Anahtar Kelimeler: Kolistin, karbapenem, kombinasyon, heterodirenç, rifampin

\section{Introduction}

Colistin is one of the last options that can be chosen for treating patients infected with carbapenem-resistant Acinetobacter baumannii complex (CR-ABC). However, in recent years, heteroresistance and resistance to colistin have been reported for CR-ABC[1,2].

For a clinical isolate, heteroresistance can be understood as the existence of both resistant and susceptible subpopulations to an antimicrobial agent. Colistin heteroresistance has been defined as an isolate with colistin minimum inhibitory concentrations (MIC) $<=2 \mathrm{mg} / \mathrm{L}$, in which detectable subpopulations were able to grow in the presence of $>2 \mathrm{mg} / \mathrm{L}$ colistin[1,3]. This heteroresistance is thought to be induced by exposure to colistin[1,4]. It was shown that heteroresistant populations may become fully resistant after continuous exposure to colistin[1,5]. Heteroresistance to colistin cannot be detected by routine antimicrobial susceptibility testing. Recently, colistin heteroresistance has been blamed for treatment failures in patients with $C R-A B C$ infections. It has been reported that colistin monotherapy might cause problems such as development of resistance and heteroresistance[6].

Most knowledge on heteroresistance to antibiotics relates to vancomycin and Staphylococcus aureus[1,7]. Limited investigations have been conducted for other bacteria[1,8]. Heteroresistance to carbapenems has been reported in $A$. baumannii, and it is believed to be the cause of increasing $C R$ A. baumannii in Greece[1,9]. Recently, Moosavian et al.[10] have reported a case of meningitis due to colistin heteroresistant $A$. baumannii and observed colistin resistance development during treatment with colistin.

According to a few in vitrostudies, colistin resistance is mediated by a complete loss of lipopolysaccharide (LPS) production via mutations in LPS producing genes or by mutations in the pmrA and $p m r B$ genes[11]. Recently, monotherapy-induced colistin resistance and (via) pmrB mutations have been detected[12].

In this study, we aimed to investigate colistin heteroresistance rates among $C R-A B C$ strains isolated from the intensive care unit (ICUs) of a university hospital. We also aimed to determine the effects of colistin and its combinations on the rate of heteroresistance/resistance using a standard $A$. baumannii strain and a clinical isolate.

\section{Materials and Methods}

During the study period from January 2010 to September 2012, a total of 31 non-repetitive CR-ABC isolates were collected from blood cultures of 25 patients who were admitted to the ICUs of a university hospital in Turkey. Blood samples were incubated in BacT/Alert Automated Blood Culture System (bioMérieux, France).

The isolates were identified as $A B C$ using the VITEK2 identification system (bioMérieux, France) and antibiograms were performed by this system. The results were evaluated according to the Clinical and Laboratory Standards Institute (CLSI 2012) guidelines[13]. The strains were stored at $-80{ }^{\circ} \mathrm{C}$ in Mueller-Hinton broth (MHB) containing 15\% glycerol. Before the study, A. baumannii ATCC 19606 and the stored bacteria were subcultured on sheep blood agar twice and they were incubated for 24 hours at $37^{\circ} \mathrm{C}$ in an incubator.

For imipenem and meropenem, antimicrobial resistance was confirmed by using Mueller-Hinton agar (MHA) and gradient antimicrobial test strips (MIC evaluator strips, Oxoid, UK). The test was performed and evaluated according to the manufacturer's recommendations and CLSI criteria[13]. P. aeruginosa ATCC 27853 and E. coli ATCC 25922 were used for quality contro|[13].

For colistin, antimicrobial susceptibilities of $A$. baumannii ATCC 19606 and the isolated bacteria were confirmed by micro broth dilution tests using cation-adjusted (CAMHB) and colistin sulfate water-soluble powder (Sigma, USA). The results were evaluated according to the CLSI criteria[13].

\section{Investigation of Heteroresistance by Direct Inoculation Into Mueller-Hinton Agar Containing Colistin}

To investigate the heteroresistant strains, the test was performed according to the method of Li et al.[1]. Before the test, all 31 isolates and ATCC 19606 strain were subcultured on sheep blood agar and incubated at $35{ }^{\circ} \mathrm{C}$ for 24 hours. From these 
subcultures, a suspension of bacteria at a turbidity equivalent to $0.5 \mathrm{McFarland}$ standard was prepared. For each strain, 100 microliters of bacterial suspension was subcultured on MHA plate containing $4 \mu \mathrm{g} / \mathrm{mL}$ colistin. At the same time, the same bacterial suspension was subcultured onto $5 \%$ sheep blood agar plate as a control. The plates were incubated at $35{ }^{\circ} \mathrm{C}$ for 48 hours and the colonies that were able to grow on agar plates were counted. Any colony that could grow on the MHA plate containing $4 \mu \mathrm{g} / \mathrm{mL}$ colistin was considered to be heteroresistant $A B C$.

\section{Investigation of Hidden Heteroresistance by Sub-inhibitory Exposure to Colistin}

For this purpose, test tubes containing $10 \mathrm{~mL}$ CAMHB and colistin at concentration of $0.5 \mathrm{x}$ MIC were inoculated with one loop of colonies from the clinical isolates and ATCC 19606 strain. Tubes were placed in a water bath (Memmert WNB14, Germany) and incubated at $37{ }^{\circ} \mathrm{C}$ with shaking rate of 100 rpm for 48 hours. After incubation, 100 microliters of bacterial suspension was taken from each tube, and subcultured on MHA plate containing $4 \mu \mathrm{g} / \mathrm{mL}$ colistin. At the same time, the same bacterial suspension was subcultured to $5 \%$ sheep blood agar plate as a control. These plates were incubated at $35{ }^{\circ} \mathrm{C}$ for 48 hours and the colonies that were able to grow on agar plates were manually counted. Any colony that could grow on the MHA plate containing $4 \mu \mathrm{g} / \mathrm{mL}$ colistin was considered to be colistin resistant [14]. Subcultures of these colistin resistant colonies were studied by broth microdilution method and it was confirmed that their MIC values became $>4 \mu \mathrm{g} / \mathrm{mL}$.

\section{Time-kill Curve Method}

Time-killing kinetics of ATCC 19606 and one ABC clinical isolate by colistin were examined[1]. The clinical isolate was randomly chosen among 31 isolates. Firstly, three colonies from each strain were inoculated in $10 \mathrm{~mL}$ CAMHB test tube and bacterial suspensions were brought to the logarithmic phase by incubation at $37^{\circ} \mathrm{C}$ for two hours. Colistin antibiotic was added to broth culture to yield concentrations of $0,0.25,0.5,1,2,4$, $8,16,32$, and $64 x$ MIC of the strain. They were placed in the incubator at $35^{\circ} \mathrm{C}$. Viable counting was performed on samples collected at 1, 2, 3, 4, 6, and 24 hour after antibiotic addition. Samples of bacterial cell suspension $(50 \mu \mathrm{L})$ were plated on nutrient agar (NA) plates. Colonies were counted manually after incubation of subcultures for 48 hours at $35^{\circ} \mathrm{C}[1]$.

Investigation of the Effects of Different Antibiotic Combinations on Heteroresistance Rates by Serial Passaging

This study was performed on A. baumannii ATCC 19606 strain and the same chosen $A B C$ clinical isolate. The effects of colistin alone and in combination with rifampicin, tigecycline, gentamicin and fluconazole on the rate of heteroresistance/ resistance were investigated by serial passaging. The serial passaging method is explained below. For the four antibiotics which would be applied in combination with colistin, MIC values of the two strains were separately tested by using the broth microdilution method. Heteroresistance preventative effects of the combinations at antimicrobial concentration levels of $0.5,2$, 8 , and $64 \mathrm{x}$ MIC were investigated by increasing concentrations of colistin and combination antibiotic day by day. A method that had been suggested by Li et al.[1] was used as below.

Serial passaging using different antibiotic combinations and concentrations:

- On day 1, $10 \mathrm{~mL}$ of 2 CAMHB media containing colistin sulfate at $0.5 \mathrm{x}$ MIC (equal to $0.25 \mu \mathrm{g} / \mathrm{mL}$ ) were separately inoculated with ATCC strain and clinical isolate from three fresh colonies (Passage 1). Cultures were incubated at $37^{\circ} \mathrm{C}$ in a shaking water bath (100 rpm) for 48 hours[1].

- On day 3, $0.1 \mathrm{~mL}$ of the culture was transferred into $10 \mathrm{~mL}$ of CAMHB containing colistin sulfate at $2 x$ MIC (Passage 2), and the cultures were incubated (see above).

On day $4,0.1 \mathrm{~mL}$ of the culture of $A B C$ from passage 2 was transferred into $10 \mathrm{~mL}$ of CAMHB containing colistin sulfate at 8x MIC (Passage 3), and the cultures were incubated.

- On day 5, $0.1 \mathrm{~mL}$ of the culture of $A B C$ from passage 3 was transferred into $10 \mathrm{~mL}$ of CAMHB containing colistin sulfate at 64x MIC (Passage 4), and the cultures were incubated.

- On day 6, cultures (5 mL) of ATCC 19606 and clinical isolate from passage 4 were centrifuged $(3,000 \mathrm{xg})$ for $10 \mathrm{~min}$ at $4{ }^{\circ} \mathrm{C}$ and washed twice with $10 \mathrm{~mL}$ of saline before being inoculated into $10 \mathrm{~mL}$ of CAMHB. Daily passaging in colistin-free CAMHB (see above) continued for 10 days for both isolates[1].

After each daily passage, 50 microliters of the culture was taken from the CAMHB test tube and inoculated onto the MHA plates containing $4 \mu \mathrm{g} / \mathrm{mL}$ of colistin sulfate. The subpopulations able to grow on MHA plates containing $4 \mu \mathrm{g} / \mathrm{mL}$ of colistin sulfate were considered to be heteroresistant. All the heteroresistant colonies were counted manually[1].

Firstly, the procedure above was performed by using colistin alone. After that, the same procedure was repeated for the combinations of colistin-gentamicin (Col+Gen), colistinrifampicin (Col+Rif), colistin-tigecycline (Col+Tig) and colistinfluconazole ( $\mathrm{Col}+\mathrm{Flu})$ to investigate the effects of combinations. During the procedure, daily exposure concentration of each antibiotic in the combination was determined according to the MIC value of strain. Concentrations of combination antibiotics (rifampicin, tigecycline, gentamicin and fluconazole) were increased just like colistin concentration at each step/day. 


\section{Results}

\section{Antibiotic Susceptibility Results}

All of the clinical isolates were found resistant to piperacillin, ampicillin/sulbactam, ceftazidime, meropenem, imipenem, tetracycline, ciprofloxacin, and trimethoprim/sulfamethoxazole. Two isolates (6.4\%) were susceptible, 12 isolates (38.7\%) were intermediate susceptible and 17 isolates (54.8\%) were resistant to gentamicin. Eight isolates (25.8\%) were susceptible, 22 isolates $(71 \%)$ were intermediate susceptible, and one isolate (3.2\%) was resistant to tigecycline. All isolates were found to be susceptible to colistin by VITEK2 identification system.

All the clinical isolates (which were resistant to carbapenems according to VITEK2 results) were found to be resistant to imipenem and meropenem after confirmation with MIC evaluator strips. For all these isolates, MIC values were $>32 \mu \mathrm{g} / \mathrm{mL}$.

Colistin MIC value for all clinical strains and standard $A$. baumannii was found to be $0.5 \mu \mathrm{g} / \mathrm{mL}$ using the broth microdilution method. All isolates were susceptible to colistin[13].

\section{Investigation of Colistin Heteroresistance}

No heteroresistant subpopulations were observed after incubation of MHA plates which were inoculated directly.

For this reason, as explained before, we investigated hidden heteroresistance by exposing the strains to colistin at subinhibitory concentrations[14]. After exposure to colistin, all 32 strains were inoculated onto MHA plates containing $4 \mu \mathrm{g} /$ $\mathrm{mL}$ colistin. All the strains could grow on these agar plates confirming that their MIC values became $>4 \mu \mathrm{g} / \mathrm{mL}$.

\section{Time-kill Curve Results}

At the end of the time-kill curve study, for both ATCC 19606 strain and chosen clinical isolate, we observed no inhibition on the NA plates that had been subcultured from suspensions containing colistin at $0,0.25,0.5$, and $1 \mu \mathrm{g} / \mathrm{mL}$ concentrations.

For both strains, we observed inhibition up to hour 6 (more significant at higher concentrations of colistin), but because of the regrowth of the bacteria, we observed a rapid increase in the number of bacteria and the selection of heteroresistant subpopulations between hour 6 and hour 24. The results of time-kill assay are summarized in Figure 1 and Figure 2.

For the clinical isolate, compared to the ATCC ABC strain, we observed a better inhibition at colistin concentrations $>=2 \mu \mathrm{g} /$ $\mathrm{mL}$ during the hour 6 when the inhibition was maximum.

When we analyzed the graphics, we observed that the number of growing colonies again increased at the end of 24 hours (regrowth). However, for the clinical isolate at $32 \mu \mathrm{g} / \mathrm{mL}$ colistin concentration, we observed a significant inhibition $(\log =2)$ even at the $24^{\text {th }}$ hour. For ATCC ABC strain, this inhibition was very weak $(\log =4)$ at $32 \mu \mathrm{g} / \mathrm{mL}$ colistin concentration during the 24 hour.

\section{Serial Passaging Results Using Different Antibiotic Combinations and Concentrations}

The effects of colistin alone, Col+Gen, Col+Rif, Col+Tig and Col+Flu combinations to prevent emergence of colistin heteroresistance were tested using serial passaging. For ATCC $A B C$ strain and clinical isolate, the MIC values of the four combination antibiotics and colistin are given in Table 1 .

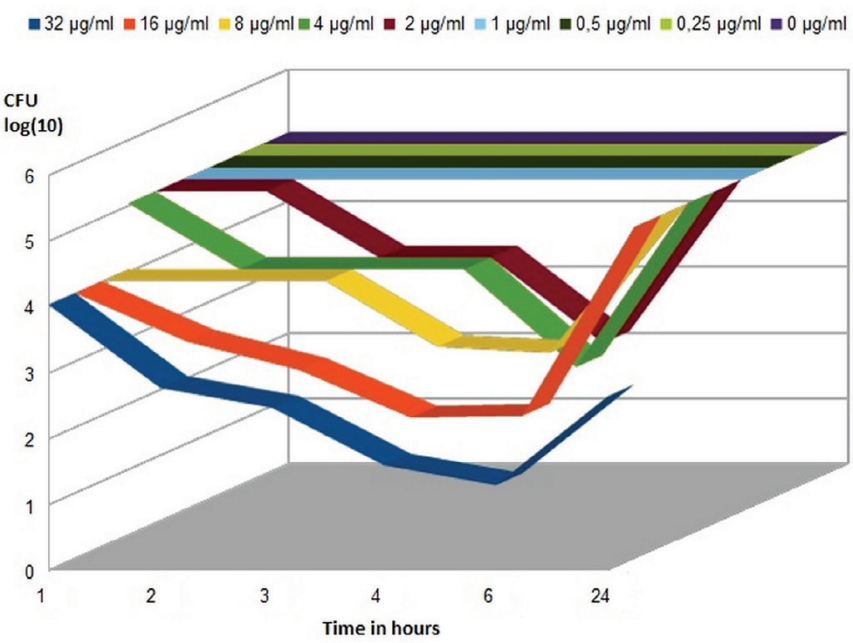

Figure 1. Time-kill curve for Acinetobacter baumannii clinical isolate. Each colored band represents different antibiotic concentration. Number of colonies $(\log 10)$ that were able to grow on agar plates are on the vertical axis

CFU: Colony-forming unit

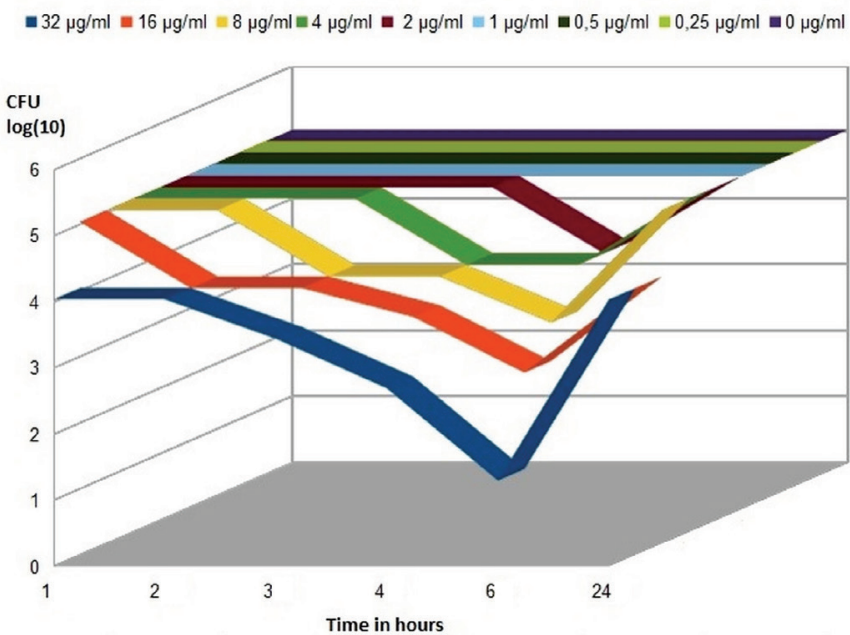

Figure 2. Time-kill curve for Acinetobacter baumannii standard American Type Culture Collection strain. Each colored band represents different antibiotic concentration. Number of colonies ( $\log 10)$ that were able to grow on agar plates are on the vertical axis

CFU: Colony-forming unit 
The count of colistin resistant colonies able to grow at $0.5,2,8$, and 64x MIC of colistin and combination antibiotics are given in Table $2 \mathrm{a}$ and $2 \mathrm{~b}$. The count of colistin resistant colonies able to grow at colistin-free broth media is also given in Table 2a and $2 b$.

When Table $2 \mathrm{a}$ and $2 \mathrm{~b}$ were analyzed, we observed that when colistin was applied alone, even at increased colistin concentrations (including 64x MIC level $=32 \mu \mathrm{g} / \mathrm{mL}$ colistin), the bacteria could not be inhibited and continued growing by transforming to resistant clones. For both strains, Col+Rif and Col+Tig combinations were found to be effective even at sub$\mathrm{MIC}$ concentrations $(0.5 \mathrm{x} \mathrm{MIC})$ and these combinations inhibited the growth of heteroresistant/resistant colonies (sub-MIC concentrations for clinical isolate; $0.25 \mu \mathrm{g} / \mathrm{mL}$ colistin $+0.5 \mu \mathrm{g} /$ $\mathrm{mL}$ tigecycline and $0.25 \mu \mathrm{g} / \mathrm{mL}$ colistin $+2 \mu \mathrm{g} / \mathrm{mL}$ rifampicin, subMIC concentrations for ATTC strain; $0.25 \mu \mathrm{g} / \mathrm{mL}$ colistin+0.125 $\mu \mathrm{g} / \mathrm{mL}$ tigecycline and $0.25 \mu \mathrm{g} / \mathrm{mL}$ colistin $+2 \mu \mathrm{g} / \mathrm{mL}$ rifampicin).

While Col+Gen combination was effective against naive ATCC ABC strain at all concentrations including sub-MIC concentration, this combination was found to be ineffective against the clinical isolate at $0.5,2$, and $8 \times$ MIC concentrations. Col+Gen combination was effective against the clinical isolate only at $64 x$ MIC. Colistin-fluconazole combination failed to inhibit the emergence of resistant bacteria at all antimicrobial concentrations.

\section{Discussion}

Colistin heteroresistance and selection of resistant strains are significant problems for CR-ABC. In recent years, there has been an increase in isolation of colistin resistant and heteroresistant $A B C$ strains[3,15-18].

Li et al.[1] demonstrated heteroresistance $(>2 \mu \mathrm{g} / \mathrm{mL})$ in 15 strains among 16 isolates. In a study in 2008, Yau et al.[3] detected 23\% colistin heteroresistance and 3.3\% colistin resistance among 30 Acinetobacter isolates. Hawley et al.[4] detected 100\% heteroresistance among 21 patients in the United States. Later, in their studies in Argentine, Rodriguez et al.[19] Rodriguez et al.[20] have found $46 \%$ and $43 \%$ heteroresistance rates in 2009 and 2010, respectively. In their case report, Moosavian et al..[10] have recently demonstrated post neurosurgical meningitis due to colistin heteroresistant $A$. baumannii. They have also reported the generation of colistin resistant $A$. baumannii from colistin susceptible-heteroresistant strains during colistin therapy. However, in our study, we observed that colistin resistance may easily develop from colistin non-heteroresistant strains by exposure to colistin.

Our study isolates were investigated in another thesis study by Özbey[21]. The isolates showed clonal similarity at arbitrarily primed polymerase chain reaction with $\mathrm{M} 13$ and DAF4 primers[21]. The reason for what we could not detect heteroresistance may be the fact that all the ICU isolates in the study were from the same clone. Detection of colistin heteroresistant $A$. baumannii provides a strong warning that colistin is used inappropriately[22]. Moreover, previous use of colistin might be a risk factor for a higher rate of heteroresistance[4]. When we were performing the study, colistin was used very rarely in Turkey. Therefore this may be another reason why we could not detect heteroresistance. All our isolates were non-heteroresistant, but later, we isolated a colistin resistant $A B C$ from the cerebrospinal fluid of a study patient. Also, all our non-heteroresistant study isolates became colistin resistant after sub-inhibitory colistin exposure. Thus, we assume that routine usage of heteroresistance detection methods may not be appropriate to predict colistin resistance development in the future. According to our experience, to avoid selection of colistin resistance, combination therapy should also be used in non-heteroresistant cases. Therefore on this point, we contradict Rodriguez et al.[23] who have previously compared colistin heteroresistant and nonheteroresistant $A B C$ meningitis cases and found that colistin monotherapy was effective in non-heteroresistant cases.

During time-kill assays (Figure 1,2) for ATC ABC and clinical isolate, we observed no inhibition at $0,0.25,0.5$ and $1 \mu \mathrm{g} / \mathrm{mL}$ colistin concentrations. Colistin was completely ineffective at the same concentration of MIC level of the bacteria and even one dilution over this MIC level. The growth at $1 \mu \mathrm{g} / \mathrm{mL}$ concentration was thought to be caused by small amount of $A B C$ subpopulations with $\mathrm{MIC}=1 \mu \mathrm{g} / \mathrm{mL}$ in the population. This reminds us to emphasize the use of colistin at appropriate doses.

Table 1 . The minimum inhibitory concentration values of each antibiotic to be used in combination during assay ( $\mu \mathrm{g} / \mathrm{mL})$

\begin{tabular}{l|c|c}
\hline Antibiotics & A. baumannii clinical isolate & A. baumannii ATCC 19606 \\
\hline Colistin & 0.5 & 0.5 \\
\hline Rifampicin & 4 & 4 \\
\hline Gentamicin & 2 & 8 \\
\hline Tigecycline & 1 & 0.25 \\
\hline Fluconazole & $>64$ & $>64$ \\
\hline
\end{tabular}

A. baumannii: Acinetobacter baumannii, ATCC: American Type Culture Collection 
Existence of a re-growth within 24 hours suggests to use colistin drug in combination with other antibiotics. Since there is no complete inhibition even at high colistin concentrations, we consider that colistin dosage regimens should be reviewed and increased to higher levels if possible. As a matter of fact, during our thesis study, optimal dosage regimens for colistin were updated and increased up to three times[24].

Table 2a. Serial passaging results at different antibiotic combinations and concentrations for American Type Culture Collection standard Acinetobacter baumannii strain (CFU/mL)

\begin{tabular}{|c|c|c|c|c|c|}
\hline & Colistin alone & Col+Gen & Col+Rif & Col+Tig & Col+Flu \\
\hline $0.5 x \mathrm{MIC}$ & $>100000$ & 0 & 0 & 0 & $>100000$ \\
\hline 2x MIC & $>100000$ & 0 & 0 & 0 & $>100000$ \\
\hline 8x MIC & $>100000$ & 0 & 0 & 0 & $>100000$ \\
\hline 64x MIC & $>100000$ & 0 & 0 & 0 & $>100000$ \\
\hline 1 st day * & $>100000$ & 0 & 0 & 0 & $>100000$ \\
\hline $2^{\text {nd }}$ day $^{*}$ & $>100000$ & 0 & 0 & 0 & $>100000$ \\
\hline $3^{\text {rd }}$ day $^{*}$ & $>100000$ & 0 & 0 & 0 & $>100000$ \\
\hline $4^{\text {th }} \mathrm{day}^{*}$ & $>100000$ & 0 & 0 & 0 & $>100000$ \\
\hline $5^{\text {th }} d a y^{*}$ & $>100000$ & 0 & 0 & 0 & $>100000$ \\
\hline $6^{\text {th }}$ day $^{*}$ & $>100000$ & 0 & 0 & 0 & $>100000$ \\
\hline $7^{\text {th }}$ day $^{*}$ & $>100000$ & 0 & 0 & 0 & $>100000$ \\
\hline $8^{\text {th }}$ day $^{*}$ & $>100000$ & 0 & 0 & 0 & $>100000$ \\
\hline $9^{\text {th }}$ day $^{*}$ & $>100000$ & 0 & 0 & 0 & $>100000$ \\
\hline $10^{\text {th }}$ day $^{*}$ & $>100000$ & 0 & 0 & 0 & $>100000$ \\
\hline
\end{tabular}

*Passages in colistin free broth, Col+Gen: Colistin-gentamicin, Col+Rif: Colistin-rifampicin, Col+Tig: Colistin-tigecycline, Col+Flu: Colistin-fluconazole, MIC: Minimum inhibitory concentration, CFU: Colony-forming unit

Table 2b. Serial passaging results at different antibiotic combinations and concentrations for Acinetobacter baumannii clinical isolate $(\mathrm{CFU} / \mathrm{mL})$

\begin{tabular}{|c|c|c|c|c|c|}
\hline & Colistin alone & Col+Gen & Col+Rif & Col+Tig & Col+Flu \\
\hline $0.5 x \mathrm{MIC}$ & $>100000$ & $>100000$ & 0 & 0 & $>100000$ \\
\hline $2 \times \mathrm{MIC}$ & $>100000$ & $>100000$ & 0 & 0 & $>100000$ \\
\hline 8x MIC & $>100000$ & 10000 & 0 & 0 & $>100000$ \\
\hline 64x MIC & $>100000$ & 0 & 0 & 0 & $>100000$ \\
\hline $1^{\text {st }}$ day * & $>100000$ & 0 & 0 & 0 & $>100000$ \\
\hline $2^{\text {nd }} \mathrm{day}^{*}$ & $>100000$ & 0 & 0 & 0 & $>100000$ \\
\hline $3^{\text {rd }}$ day $^{*}$ & $>100000$ & 0 & 0 & 0 & $>100000$ \\
\hline $4^{\text {th }}$ day $^{*}$ & $>100000$ & 0 & 0 & 0 & $>100000$ \\
\hline $5^{\text {th }}$ day $^{*}$ & $>100000$ & 0 & 0 & 0 & $>100000$ \\
\hline $6^{\text {th }}$ day $^{*}$ & $>100000$ & 0 & 0 & 0 & $>100000$ \\
\hline $7^{\text {th }}$ day $^{*}$ & $>100000$ & 0 & 0 & 0 & $>100000$ \\
\hline $8^{\text {th }}$ day $^{*}$ & $>100000$ & 0 & 0 & 0 & $>100000$ \\
\hline $9^{\text {th }}$ day $^{*}$ & $>100000$ & 0 & 0 & 0 & $>100000$ \\
\hline $10^{\text {th }}$ day $^{*}$ & $>100000$ & 0 & 0 & 0 & $>100000$ \\
\hline
\end{tabular}

*Passages in colistin free broth, Col+Gen: Colistin-gentamicin, Col+Rif: Colistin-rifampicin, Col+Tig: Colistin-tigecycline, Col+Flu: Colistin-fluconazole, MIC: Minimum inhibitory concentration, CFU: Colony-forming unit 
During serial passaging, application of colistin alone could not inhibit the strains even at increased colistin concentrations. Moreover, the strains transformed to colistin resistant clones and continued growing (Table 2). In accordance with the previous time kill study; this indicates that colistin monotherapy should be avoided during treatment.

Colistin-rifampicin combination inhibited growth of heteroresistant clones even at subinhibitory concentrations (Table 2). In accordance with this, several studies and case reports confirmed the inhibitory effect of Col+Rif combination[25]. In a study performed in 2005, Timurkaynak et al.[26] showed that the combination of colistin and rifampicin was synergistic against multidrug-resistant $A$. baumannii isolates. Rodriguez et al.[20] reported that this combination was very effective and prevented the emergence of colistin resistant mutants. In a study in 2011, Liang et al.[27] reported that this combination acted synergistically against $A$. baumannii. In a prospective study in 2012, Aydemir et al.[28] suggested that Col+Rif combination may improve clinical and microbiological outcomes of ventilator-associated pneumonia patients infected with CR A. baumannii. In a study in 2013, Lee et al.[29] have shown that the combination of colistin and rifampin increased killing rate of both multidrug resistant colistin susceptible and resistant $A$. baumannii and that combination therapy prevented or suppressed the emergence of colistin-resistant subpopulations. Dong et al.[30] showed that the combinations of Col+Rif, rifampin-sulbactam, rifampin-tigecycline and sulbactam-tigecycline showed good in vitro activities (addictive or partially synergistic) against extensively drug-resistant $A$. baumannii isolates even at subinhibitory concentrations. Our findings were in accordance with these studies. According to the results of our study, rifampicin may be a good combination alternative.

Colistin-tigecycline combination was effective against both strains even at subinhibitory concentrations (Table 2). In an in vitro study in 2010, Ozbek and Senturk[31] reported the synergistic effect of Col+Tig against meropenem resistant $A B C$. In a study in 2012, Peck et al.[32] reported that this combination was synergistic and had bactericidal effects even at $0.5 \mathrm{x}$ MIC antibiotic concentration. Therefore, we also assume that tigecycline may be another combination alternative.

We included gentamicin in our study as representative of the aminoglycoside group. Colistin-gentamicin combination was effective against the naive ATCC ABC strain. The combination was effective against the clinical isolate only at $64 x \mathrm{MIC}$ level, but it may not be possible to use this combination at such high doses for treatment. As a result; even if this combination had weak effects on the emergence of colistin resistance, it is not practical to use this combination for treatment.
In the literature, there are very few reports of the effects of colistin in combination with an aminoglycoside, but no reports of the combination of colistin and gentamicin. In 2005, Fulnecky et al.[33] reported a case of post-surgical meningitis due to a multidrug resistant $A$. baumannii. Upon administration of colistin plus amikacin combination, the patient experienced successful clinical and microbiological outcomes.

In the literature, there are rare reports investigating the effects of polymyxins in combination with an antifungal, but these are only about fungi species[34]. In ICUs, we observed that some hospitalized patients treated with colistin are given fluconazole at the same time. Thus, we also studied fluconazole combination to see whether it has effects on bacterial heteroresistance or not.

In this study, we observed that colistin in combination with rifampicin or tigecycline was effective even at sub-MIC concentrations and prevented heteroresistance to colistin. When we evaluate this result in the light of clinically obtained colistin concentrations, we can comment that routine clinical dosage of colistin could be effective in combination with suggested drugs. However, colistin monotherapy was found to be ineffective even at $32 \mu \mathrm{g} / \mathrm{mL}$ (64x MIC) colistin concentration which is higher than clinically obtained maximum serum level of $20 \mu \mathrm{g} / \mathrm{mL}[35]$.

Our study may be the first colistin heteroresistance study for A. baumannii strains from Turkey. At the same time, this could be the first study investigating effects of gentamicin-colistin combinations on colistin heteroresistance in the literature. However, this study has some limitations which have to be pointed out. This study is an in vitro study and needs to be supported by in vivo studies. There are some previous reports with similar findings. As another limitation, all the strains included in the study were from the unique university hospital in our region and they were from the same clone, but we could not study isolates from different hospitals of other cities to represent a larger universe. We could include small number of strains in serial passaging step. Furthermore, we did not perform synergy testing in our study.

In a recent study investigating synergistic antimicrobial activity of plant extracts, no significant antimicrobial activity was observed for multidrug resistant $A$. baumannii[36]. Several in vitro studies reported synergistic effects between diverse drugs for the treatment of Acinetobacter[26,29-32,37]. However, more in vivo studies about these combinations are needed to provide high grade of evidence. Since there are various synergy test reports with disputable and different results, it would be better to develop rapid and practical synergy tests that could be used in clinical settings. Further studies including different $A B C$ clones isolated from different hospitals are needed to obtain more accurate results. 


\section{Conclusion}

At the end of our study, Col+Rif and Col+Tig combinations were found to be effective and prevented the emergence of heteroresistance to colistin. At low concentrations, Col+Gen combination was ineffective against the clinical $A B C$ isolate.

Colistin is one of the last options that can be chosen for the treatment of multidrug resistant $A B C$ infections. So as not to lose this last resort drug, antibiotic treatment regimens must be chosen very carefully. In the light of research in the literature and forthcoming studies, colistin should be used at the updated high doses and in combination with another antibiotic.

\section{Acknowledgements}

This study was supported by University Scientific Research Projects Commission project number 2012-028. Language proofreading was performed by Catherine Yiğit, The Skaian Gates Translation Office.

\section{Ethic}

Ethics Committee Approval: During the date when our study was performed (2012), Ethical Committee approval wasn't needed for in vitro experimental studies from patient's sample according to the valid rule of Clinical Investigations date: 19.08.2011 and 'Resmi Gazete' number: 28030, Informed consent: Consent form was not needed for in vitro studies from patient samples.

Peer-review: externally and internally peer-reviewed.

\section{Authorship Contributions}

Surgical and Medical Practices: D.G., M.T.O., Concept: D.G., M.T.O., Design: D.G., M.T.O., Data Collection or Processing: D.G., M.T.O., Analysis or Interpretation: D.G., M.T.O., Literature Search: D.G., M.T.O., Writing: D.G., M.T.O.

Conflict of Interest: No conflict of interest was declared by the authors.

Financial Disclosure: The authors declared that this study received no financial support.

\section{References}

1. Li J, Rayner CR, Rayner CR, Nation RL, Owen RJ, Spelman D, Tan KE, Liolios L. Heteroresistance to colistin in multidrug-resistant Acinetobacter baumannii. Antimicrob Agents Chemother. 2006;50:2946-50.

2. Souli $M$, Kontopidou $F$, Koratzanis $E_{1}$ Antoniadou A, Giannitsioti $E_{1}$ Evangelopoulou P, Kannavaki S, Giamarellou H. In vitro activity of tigecycline against multiple-drug-resistant, including pan-resistant, gram-negative and gram-positive clinical isolates from Greek hospitals. Antimicrob Agents Chemother. 2006;50:3166-9.

3. Yau W, Owen RJ, Poudyal A, Bell JM, Turnidge JD, Yu HH, Nation RL, Li J. Colistin hetero-resistance in multidrug-resistant Acinetobacter baumannii clinical isolates from the Western Pacific region in the SENTRY antimicrobial surveillance programme. J Infect. 2009;58:138-44.
4. Hawley JS, Murray CK, Jorgensen JH. Colistin heteroresistance in Acinetobacter and its association with previous colistin therapy. Antimicrob Agents Chemother. 2008;52:351-2.

5. Tan $\mathrm{CH}, \mathrm{Li} \mathrm{J}$, Nation RL. Activity of colistin against heteroresistant Acinetobacter baumannii and emergence of resistance in an in vitro pharmacokinetic/pharmocodynamic model. Antimicrob Agents Chemother. 2007;51:3413-5.

6. Rolain JM, Roch A, Castanier M, Papazian L, Raoult D. Acinetobacter baumannii resistant to colistin with impaired virulance: a case report from France. J Infect Dis. 2011;204:1146-7.

7. Hiramatsu K. Vancomycin-resistant Staphylococcus aureus: a new model of antibiotic resistance. Lancet Infect Dis. 2001;1:147-55.

8. Rinder $\mathrm{H}$. Hetero-resistance: an under-recognised confounder in diagnosis and therapy? J Med Microbiol. 2001;50:1018-20.

9. Pournaras $\mathrm{S}$, Ikonomidis $\mathrm{A}$, Markogiannakis $\mathrm{A}$, Maniatis AN, Tsakris A. Heteroresistance to carbapenems in Acinetobacter baumannii. J Antimicrob Chemother. 2005;55:1055-6.

10. Moosavian M, Shoja S, Nashibi R, Ebrahimi N, Tabatabaiefar MA, Rostami $\mathrm{S}$, Peymani A. Post neurosurgical meningitis due to colistin heteroresistant Acinetobacter baumannii. Jundishapur J Microbiol. 2014;7:e12287.

11. Moffatt $J H$, Harper $M$, Harrison $P$, Hale JD, Vinogradov $E$, Seemann $T$, Henry R, Crane B, St Michael F, Cox AD, Adler B, Nation RL, Li J, Boyce JD. Colistin resistance in Acinetobacter baumannii is mediated by complete loss of lipopolysaccharide production. Antimicrob Agents Chemother 2010;54:4971-7.

12. Kim $Y$, Bae IK, Jeong SH, Yong $D$, Lee $K$. In vivo selection of pan-drug resistant Acinetobacter baumannii during antibiotic treatment. Yonsei Med J. 2015;56:928-34.

13. Clinical and Laboratory Standards Institute (CLSI). Performance standards for antimicrobial disk susceptibility tests; Twenty-second informational supplement. USA; 2012.

14. Soon RL, Nation RL, Hartley PG, Larson I, Li J. Atomic force microscopy investigation of the morphology and topography of colistin-heteroresistant Acinetobacter baumannii strains as a function of growth phase and in response to colistin treatment. Antimicrob Agents Chemother. 2009;53:4979-86.

15. Ko KS, Suh JY, Kwon KT, Jung SI, Park KH, Kang Cl, Chung DR, Peck KR, Song $\mathrm{JH}$. High rates of resistance to colistin and polymyxin $\mathrm{B}$ in subgroups of Acinetobacter baumannii isolates from Korea. J Antimicrob Chemother. 2007;60:1163-7.

16. Al-Sweih NA, Al-Hubail MA, Rotimi VO. Emergence of tigecycline and colistin resistance in Acinetobacter species isolated from patients in Kuwait hospitals. J Chemother. 2011;23:13-6.

17. Lee SC, Huang SS, See LC, Tsai MH, Shieh WB. In vitro activities of nine current antibiotics against culprit bacteria in nosocomial infections in an institution in Northern Taiwan. Chang Gung Med J. 2011;34:580-9.

18. Eser Ö, Ergin A, Hasçelik G. Acinetobacter türlerinde antimikrobiyal direnç ve metallo-beta-laktamaz varlığı. Mikrobiyoloji Bul. 2009;43:383-90.

19. Rodriguez $\mathrm{CH}$, Bombicino K, Granados G, Nastro M, Vay C, Famiglietti A. Selection of colistin-resistant Acinetobacter baumannii isolates in postneurosurgical meningitis in an intensive care unit with high presence of heteroresistance to colistin. Diagn Microbiol Infect Dis. 2009;65:18891.

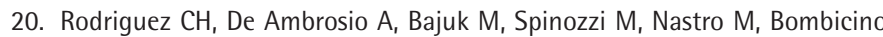
K, Radice M, Gutkind G, Vay C, Famiglietti A. In vitro antimicrobials activity against endemic Acinetobacter baumannii multiresistant clones. J Infect Dev Ctries. 2010;4:164-7.

21. Özbey N. Karbapenemlere dirençli Acinetobacter baumannii izolatlarında moleküler tiplendirme ve karbapenemazların araştırılması. (Tez). Çanakkale: Çanakkale Onsekiz Mart Üniversitesi, Tıp Fakültesi; 2012. 
22. Li J, Rayner CR, Nation RL, Deans R, Boots R, Widdecombe N, Douglas A, Lipman J. Pharmacokinetics of colistin methanesulfonate and colistin in a critically ill patient receiving continuous venovenous hemodiafiltration. Antimicrob Agents Chemother. 2005;49:4814-5.

23. Rodriguez $C_{\text {, B }}$ Barberis $C$, Nastro $M$, Bombicino $K$, Granados G, Vay $C$, Famiglietti A. Impact of heteroresistance to colistin in meningitis caused by Acinetobacter baumannii. J Infect. 2012;64:119-21.

24. Gilbert DN, Moellering RC, Eliopoulos GM, Chambers HF, Saag MS. The Sanford Guide to Antimicrobial Therapy. $42^{\text {nd }}$ ed. Sperryville, USA: Antimicrobial Therapy Inc; 2012.

25. Pachon-lbanez ME, Docobo-Perez $F$, Lopez-Rojas R, Dominguez-Herrera J, Jimenez-Mejias ME, Garcia-Curiel A, Pichardo C, Jimenez L, Pachon J. Efficacy of rifampin and its combinations with imipenem, sulbactam, and colistin in experimental models of infection caused by imipenem-resistant Acinetobacter baumannii. Antimicrob Agents Chemother. 2010;54:116572.

26. Timurkaynak F, Can F, Azap OK, Demirbilek M, Arslan H, SO Karaman. In vitro activities of non-traditional antimicrobials alone or in combination against multidrug-resistant strains of Pseudomonas aeruginosa and Acinetobacter baumannii isolated from intensive care units. Int J Antimicrob Agents. 2006;27:224-8

27. Liang W, Liu XF, Huang J, Zhu DM, Li J, Zhang J. Activities of colistin and minocycline-based combinations against extensive drug resistant Acinetobacter baumannii isolates from intensive care unit patients. BMC Infect Dis. 2011;11:109.

28. Aydemir H, Akduman D, Piskin N, Comert F, Horuz E, Terzi A, Kokturk F, Ornek T, Celebi G. Colistin vs. the combination of colistin and rifampicin for the treatment of carbapenem-resistant Acinetobacter baumannii ventilator-associated pneumonia. Epidemiol Infect. 2013;141:121422.
29. Lee HJ, Bergen PJ, Bulitta JB, Tsuji B, Forrest A, Nation RL, Li J. Synergistic activity of colistin and rifampin combination against multidrug-resistant Acinetobacter baumannii in an in vitro pharmacokinetic/pharmacodynamic model. Antimicrob Agents Chemother. 2013;57:3738-45.

30. Dong $X$, Chen F, Zhang Y, Liu H, Liu Y, Ma L. In vitro activities of rifampin, colistin, sulbactam and tigecycline tested alone and in combination against extensively drug-resistant Acinetobacter baumannii. J Antibiot. 2014;67:677-80.

31. Ozbek B, Senturk A. Postantibiotic effects of tigecycline, colistin sulfate, and levofloxacin alone or tigecycline-colistin sulfate and tigecycline-levofloxacin combinations against Acinetobacter baumannii. Chemotherapy. 2010;56:466-71.

32. Peck KR, Kim MJ, Choi JY, Kim HS, Kang Cl, Cho YK, Park DW, Lee HJ, Lee MS, Ko KS. In vitro time-kill studies of antimicrobial agents against blood isolates of imipenem-resistant Acinetobacter baumannii, including colistin or tigecycline resistant isolates. J Med Microbiol. 2012;61:353-60.

33. Fulnecky EJ, Wright D, Scheld WM, Kanawati L, Shoham S. Amikacin and colistin for treatment of Acinetobacter baumannii meningitis. J Infect. 2005;51:249-51.

34. Zhai B, Zhou H, Yang L, Zhang J, Jung K, Giam CZ, Xiang X, Lin X. Polymyxin $B$, in combination with fluconazole, exerts a potent fungicidal effect. J Antimicrob Chemother. 2010;65:931-8.

35. Food and Drug Administration (FDA). Last accessed date: 9 October 2016. Available from: http://www.fda.gov/ohrms/dockets/dockets/05p0050/05p0050-cp00001-Attachment-01.pdf.

36. Farooqui A, Khan A, Borghetto I, Kazmi SU, Rubino S, Paglietti B. Synergistic antimicrobial activity of Camellia sinensis and Juglans regia against multidrug-resistant bacteria. PLoS One. 2015;10:e0118431.

37. Tuon FF, Rocha JL, Merlini AB. Combined therapy for multi-drug-resistant Acinetobacter baumannii infection - is there evidence outside the laboratory? J Med Microbiol. 2015;64:951-9. 